\title{
ФУНКЦІЇ ІКОНІЧНОГО СКЛАДНИКА У МУЛЬТИМОДАЛЬНОМУ ХУДОЖНЬОМУ ПРОЗОВОМУ ТЕКСТІ РОМАНУ ДЖОНАТА САФРАНА ФОЕРА «СТРАШЕННО ГОЛОСНО І НЕЙМОВІРНО БЛИЗЬКО»
}

\begin{abstract}
Анотація. Потреби суспільства змінюються з розвитком технологій. Сьогодні людство не уявляе існування без використання фотографій. Фото заполонили світ. У свою чергу, література набула більш різноманітного спектру вибору мови, який віддзеркалюеться на уявленні про світ як картину, за рахунок руйнування та порушення традиційних уявлень про розповідь, читання та письмо. Тому письменники використовують усю сукупність мовних і немовних засобів для прагматичного впливу на адресата, таким чином роблячи свій твір оригінальним та самобутнім. Тому для сучасних лінгвістів виникла потреба у вивчені функцій іконічного складника у мультимодальному художньому прозовому тексті. Актуальність дослідження зумовлена недостатнім вивченням іконічного складника у мультимодальному художньому прозовому тексті. Головною метою статті є дослідити функції невербального (іконічного) складника мультимодального художнього прозового тексту. Розв'язання поставленого завдання потребує проведення контекстологічного аналізу мультимодального художнього прозового тексту та визначення функцій його складників. У статті розтлумачується значення іконічного складника. Розглянуто його універсальні функції: інформативну, експресивну, атрактивну та естетичну. Специфічні функції іконічного складника, а власне ілюстративну, символічну, стилістичну, асоціативну та адитивну функції були також проаналізовані у роботі. У статті проведено дослідження на основі роману Джонатана Сафрана Фоера Страшенно голосно і нейловірно близько. Цільові установки й завдання визначили комплексну методику аналізу фактичного матеріалу. Поряд із загальними методами наукового пізнання (описол, узагальненнял, індукиією, дедукиією), використано фрункційний метод дослідження мультимодального художнього прозового тексту.
\end{abstract}

Ключові слова: іконічний складник, вербальний складник, мультимодальний художній прозовий текст, роман, функції.

Karp Marta, Yaremchuk Tetiana Lviv Polytechnic National University

\section{FUNCTIONS OF ICONIC COMPONENT IN MULTIMODAL FICTIONAL PROSE TEXT OF JONATHAN SAFRAN FOER'S NOVEL «EXTREMELY LOUD AND INCREDIBLY CLOSE»}

Summary. The needs of society change with the development of technology. Today, humanity cannot imagine existence without the use of photographs. Photos flooded the world. In turn, literature has acquired a more diverse range of language choices, which is reflected in the perception of the world as a picture, due to the destruction and disruption of traditional visions of storytelling, reading and writing. Therefore, writers use the whole set of linguistic and non-linguistic means to pragmatically influence the addressee, thus making their work original. For modern linguists there is a need to study the functions of the iconic component in a multimodal fictional prose text. The relevance of the study is due to insufficient study of the iconic component in the multimodal fictional prose text. The main aim of the article is to explore the functions of the non-verbal (iconic) component of a multimodal fictional prose text. Solving this problem requires a functional analysis of multimodal fictional prose text. The article explains the meaning of the iconic component in the multimodal fictional prose text. Images not only complement the information, but also expand the meaning of the text. By dint of it, the addressee's attention puts on to the novel. The iconic component also helps the author to create symbols and images in the text of the novel and to evoke a number of associations by the reader with the given image. We have considered universal functions of iconic component: informative, expressive, attractive and aesthetic. Specific functions of the iconic component, as well as illustrative, symbolic, stylistic, associative and additive functions have been also analyzed in this work. The article is based on the novel Extremely loud and incredibly close by Jonathan Safran Foer. The aim and tasks defined a comprehensive methodology for analyzing the actual material. Along with functional, semiotic and narrative analyses, the general methods of scientific cognition (description, generalization, induction, deduction) have been also used.

Keywords: iconic component, verbal component, multimodal fictional prose text, novel, functions.

$\Pi^{2}$ остановка проблеми. У сучасному суспільстві зросла тенденція до передавання та опосередковування інформації за допомогою фото. Поширення фото є не тільки характеристикою XXI століття, але й важливим засобом відображення й сприйняття світу. Як результат література набула більш різноманітного спектру вибору мови, який відбивається на уявленні про світ як картину, за рахунок зруйнування та порушення традиційних уяв- лень про розповідь, читання та письмо. Тому письменники використовують усю сукупність мовних і немовних засобів для прагматичного впливу на адресата. Використання автором невербальних засобів надае твору оригінальності та самобутності і також дозволяе змінити семантику вербальної частини розповіді. Саме тому виникла потреба у вивчені іконічних складників у мультимодальному художньому прозовому тексті. 
Аналіз останніх досліджень і публікацій. Питання фуннкій невербального (іконічного) складника мультимодального художнього прозового тексту досліджували Теодор Якоб ван Левен [11], Гюнтер Рольф Кресс [11], Ентоні Болдрі [9], Пол Тібо [9], Ніна Норгард [13], Марта Карп та інші. Прагнучи розробити методологію, яка дозволить аналітикам зрозуміти мультимодальні тексти Кресс і ван Левен, Болдрі й Тібо розширили основні ідеї Системної бункціональної лінгвістики Майкла Халлідея та його погляд на мову як соціальну семіотику, для того щоб охопити аналіз текстів, які є більш ніж суто словесними.

Виділення не вирішених раніше частин загальної проблеми. Актуальність дослідження зумовлена тим, що функції невербального (іконічного) складника мультимодального художнього прозового тексту все ще залишаються недостатньо вивченими та дослідженими.

Мета статті. Головною метою щіеї роботи є дослідити функції невербального (іконічного) складника мультимодального художнього прозового тексту. Розв'язання поставленого завдання потребуе проведення семіотико-наративного аналізу мультимодального художнього прозового тексту та визначення функцій його складників. Матеріалом дослідження є роман Джонатана Сафрана Фoepa Extremely loud and incredibly close.

Виклад основного матеріалу. Відомо, що іконічні знаки - це знаки, значення яких повністю визначається тим предметом, якому вони відповідають. вони об’еднуються за принципом схожості, подібності предмета та його позначення. Іконічний знак - обов'язковий елемент мультимодального художнього прозового тексту, тому він має значне функційне значення. Зображення може виконувати як універсальні функції, так і окремі, специфічні. До головних універсальних функцій відносять інформативну, експресивну, атрактивну та естетичну функції $[1$, с. 11$]$.

Індборлативна ббункиія є невід'емною складовою будь-якого знака. У свою чергу, призначення іконічного складника включає не лише повідомлення певної інформації, але й сприяе

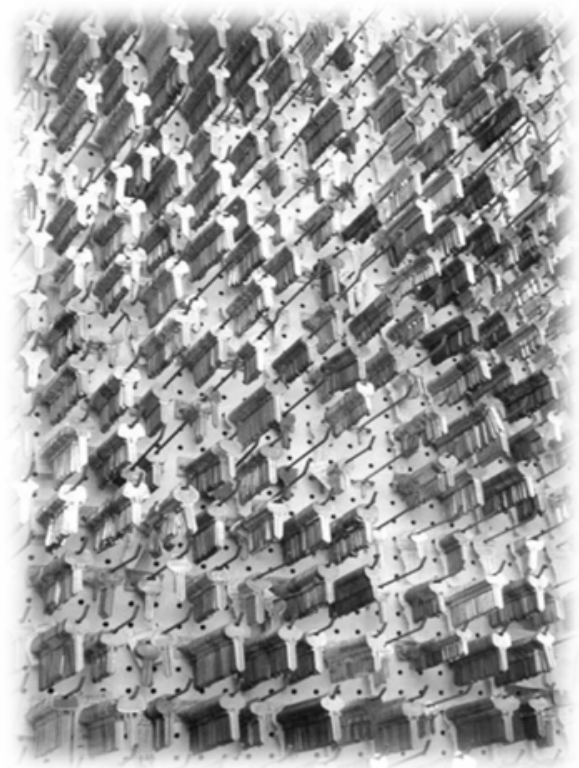

Фото 1. Ключі отриманню додаткової інформації, а також коректному витлумаченню повідомлення [5, с. 53].

Головний герой роману Джонатана Сафрана Фоера Страшенно голосно $i$ неймовірно близько Оскар Шелл використовуе свій альбом для вирізок, під назвою Усе, що зі мною трапилося, для того, щоб розповісти про події, які відбуваються 3 ним за допомогою фотографій. Цікавим $е$ те, що всі фото не супроводжуються надписами і $е$ зроблені Оскаром або завантажені з Інтернету. Таким чином, хлопчик показуе наочно, що він бачить і тим самим інформуе про події, які з ним відбуваються. Оскільки Оскар багато дізнавався про властивості ключів, то саме одним із перших зображень у його альбомі $е$ фото ключів.

За допомогою експресивної (емотивної) бункиія іконічний складник може виражати почуття адресанта та впливати на емоції адресата, тобто апелювати до його почуттів. Ця властивість може викликати у людини почуття вищого порядку. Відомо, що графічна форма тексту відображае його структуру і налаштовуе читача на емоційність та експресивність повідомлення. Однак, ця функція зосереджена на адресатові, адже один і той самий іконічний складник може викликати різні почуття у реципіента [3, с. 25].

Наприклад, зображення слона викликало захоплення у Оскара і водночас смуток у Аббі Блек. Однак, хлопчик сфотографував лише око тварини, адже воно вразило його найбільше. Це фото також може викликати співчуття до тварин у читачів, оскільки видно, що слон плаче.

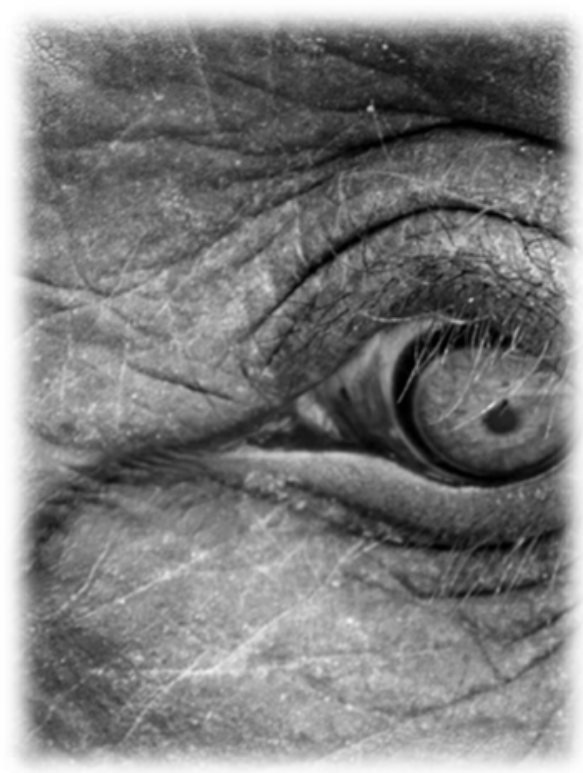

Фото 2. Слон, який плаче

Атрактивна функція привертае увагу іконічного складника в адресата, а також бере участь в організації візуальності мультимодального художнього прозового тексту. Атрактивність - це засіб привертання уваги, "сигнал взаемодії та узгодження смислових та емоційних полів комунікатора та реципієнта" [7, с. 174].

Якщо відкрити книжку Джонатана Сафрана Фoepa Extremely loud and incredibly close, то одразу на першій сторінці адресант побачить зображення дверей зі замком. Це свідчить про те, 
що у романі ітиметься про якесь розслідування або хтось шукатиме ключ до цих дверей. 3 першої сторінки автор створюе інтригу для читача.

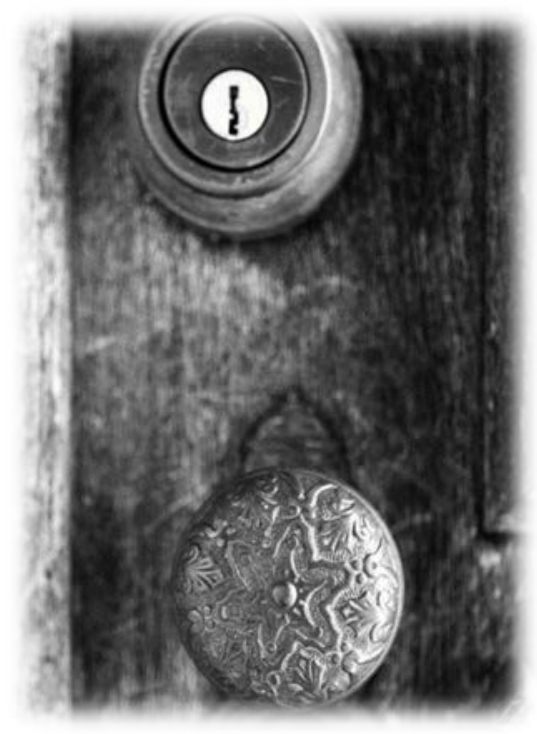

Фото 3. Замок дверей

Естетична бункиія іконічного складника полягає в тому, щоб у наочних образах, що чуттево сприймаються, реалізувати задум автора, вплинути на естетичні почуття адресата, у здатності тексту приносити естетичне задоволення чи викликати відразу. Ця фрункція реалізуеться через симетрію, пропорційність, гармонійну цілісність форми, врівноваженість кольорів [8, с. 70].

Наприклад, Оскар знаходить у магазині мистецького приладдя різнокольорові надписи, де декілька разів згадуеться ім'я його батька Томаса Шелла. Тут іконічний складних є сильним зоровим збудником, він викликає в адресата бажання вступити у комунікативний контакт із адресантом, ознайомитися із змістом вербального тексту.

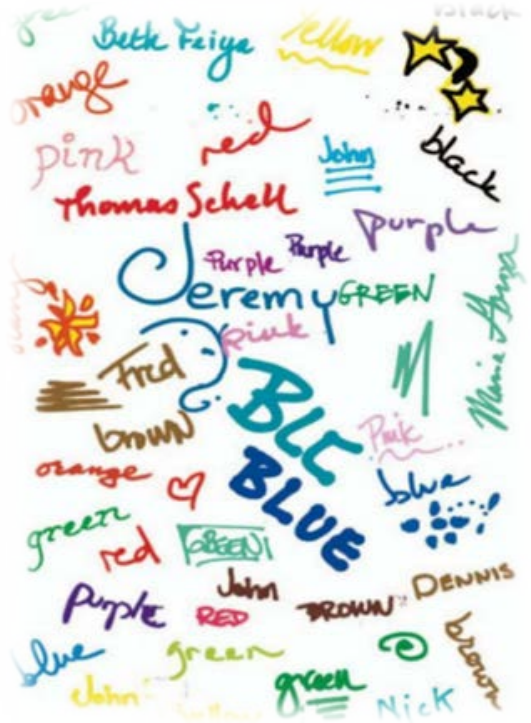

Фото 4. Сторінка блокнота з магазину мистецького приладдя
Варто розглянути й окремі специфрічні фрункції іконічного складника: ілюстративну, символічну, стилістичну, асоціативну та адитивну фрункції [2, с. 31-37].

Відтворювати повністю або частково інформацію, виражену в тексті вербально за допомогою наочних образів, що чуттево сприймаються завдання ілюстративної фбункиї. Іконічний складник не лише ілюструе вербальний, а й доповнюе, розширюе його семантику, що сприяе кращій інтерпретащії мультимодального художнього прозового тексту адресатом [9, с. 83].

Розглянемо фото, на якому зображена падаюча людина, що збільшуеться настільки, що розмите зображення якої займае всю сторінку. На цьому етапі розповіді включення цього конкретного образу не пояснюеться словесним текстом, і читач отримуе пояснення пізніше у розповіді, де виявляеться, що Оскар збільшив зображення, щоб перевірити, чи могла падаюча людина бути його батьком. На думку Кресса та ван Левена, розмір кадру i, отже, соціальна відстань між зображеними учасниками та глядачем $е$ міжособистісним візуальним ресурсом значення.
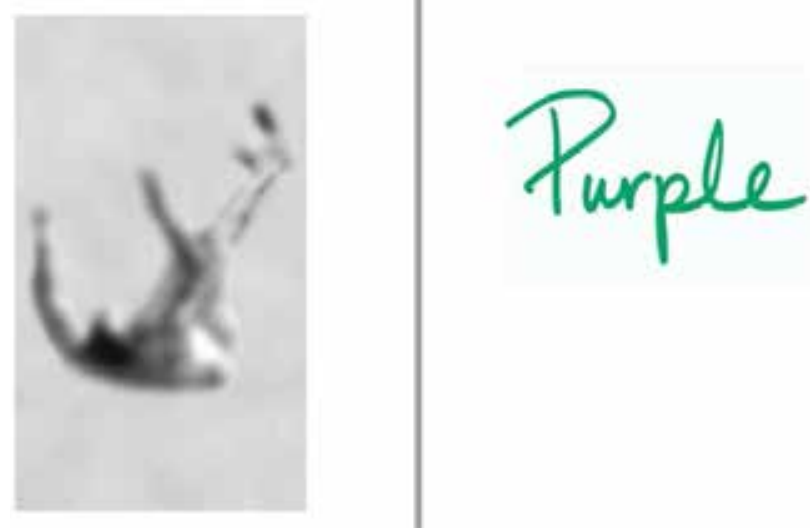

Фото 5. Падаюча людина / Надпис “Фіолетовий”

Сильолічна фбункиія іконічного складника проявляеться у його призначенні виражати за допомогою наочних образів абстрактні поняття та ідеї. Це дає змогу створювати глибокі образи. Деякі зображення-символи мають конвенційний характер і їхня інтерпретація є обмеженою, інші можуть характеризуватися множинністю інтерпретацій [12].

Повернемося до бото 4. Перше форо, яке було описане вище є символом того, що воно візуально відображає всю історію неможливих пошуків Оскара до свого батька, до якого він ніколи не зуміє наблизитися ближче, ніж до падаючої людини на зображенні. На другому фото ми бачимо, що слово Фіолетовий написане зеленим кольором. Це є символом неоднозначності, тому що на підсвідомому рівні побачивши зелений колір, людина не сприймає слово фбіолетовий. Таким чином автор зображуе віддаленість Оскара від свого батька. Хлопчик думав, що знаходиться неймовірно близько біля нього, адже його тато був у цьому магазині й, на думку головного героя, саме він написав це слово. Хоча ці дві фротографpiï на перший погляд зовсім різні, але вони символізують у романі одне й те ж саме. Ось чому 


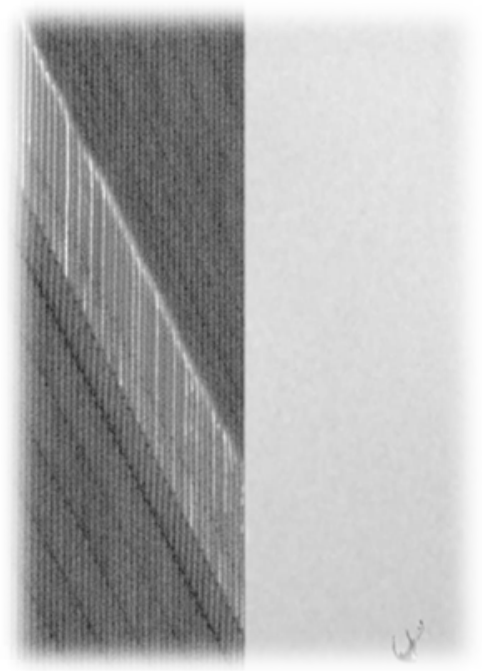

Фото 6.

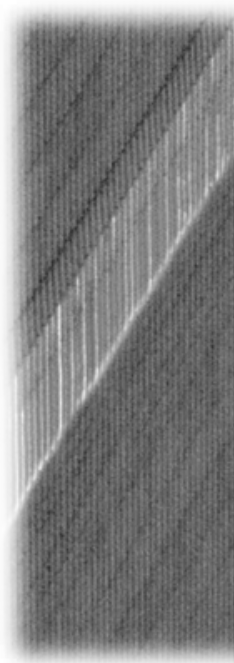

Фото 7.

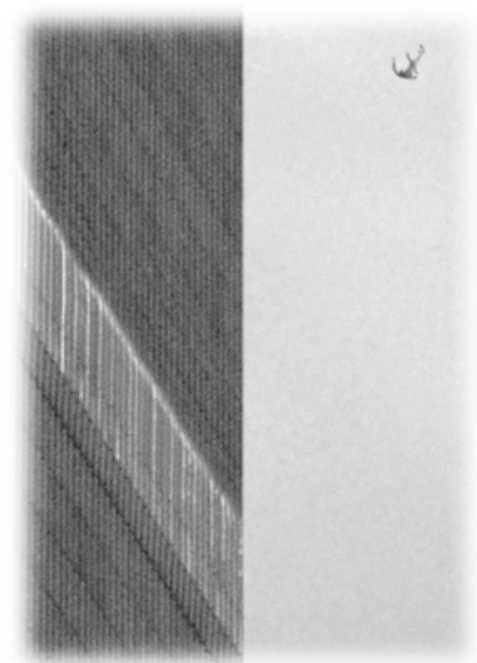

Фото 8.

Людина, яка падае з багатоповерхівки

Джонатан Сафрран Фоер розмістив, здавалося б, два різні зображення разом.

Іконічний складник також відіграє й стилістичну бункиію. Адже він може замінювати паралінгвістичні засоби усного спілкування (тон, інтонацію, гучність вимовляння, сміх, міміку, жести, позу, ходу), що слугують для стилістичного оформлення висловлювання, та допомагати “уявному виконанню” висловлювання [4, с. 137].

Образ падаючої людини відіграє центральну роль у романі Фоера: як учасник усної розповіді, як візуальний образ, до якого читачі мають ставитися безпосередньо, та як вербально-візуальні цілісні зв'язки, що пов'язують розповідь між собою. На додаток до цього, Оскар до кінця роману усвідомлюе, що він може роздрукувати 30браження падаючої людини, змінити їх порядок, погортати їх, як у книзі, і тим самим змусити чоловіка піднятися вгору замість того, щоб падати. Останні п’ятнадцять сторінок роману Дж.С. Фоера складаються 3 цих образів, тим самим запрошуючи читача відіграти активну роль у створенні сенсу, гортаючи останні сторінки роману, щоб

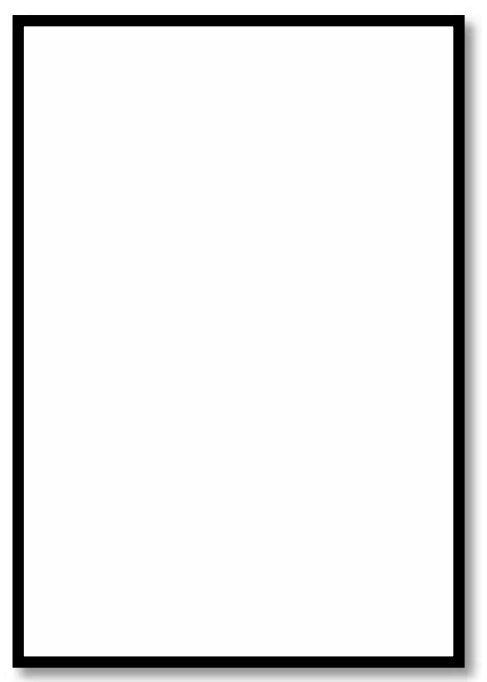

Фото 9. Пуста сторінка змусити людину телепортувати від Реального до Ідеального. Зрештою, цей елемент наративу, здається, будує своєрідну міжособистісну візуальну кінестетичну "пропозищію”, що означає “ти можеш змусити чоловіка знову піднятися, якщо хочеш”. Хоча, звичайно, можна налаштувати адресата погортати сторінки у зворотному порядку.

Асочіативна (характерологічна) ббункиія полягає в здатності паралінгвістичних засобів викликати у адресата певні часові, національні, соціальні асоціації [13, с. 254]. Якщо повернутися до зображення падаючої людини, то у багатьох людей, які знають про теракт 11 вересня 2001 року, виникатимуть асоціації 3 цим страшним днем.

Адитивна бункиія іконічного складника полягає у доповненні чи розширенні смислу тексту. Для цього типу фуннщії характерна тісна цілісність іконічного та вербального елементів $[11$, с. 93]. Для прикладу, пусті сторінки у романі є відображенням мовчання.

Висновки і пропозиції. Отже, завдяки згаданим вище прикладам, можна стверджувати, що іконічний складник відіграє важливу роль у мультимодальному художньому прозовому тексті. Адже зображення не тільки доповнюють інформацію, але й розширюють смисл тексту. Також завдяки фото привертається увага адресата й викликаються у нього певні почуття та емоції. Іконічний складник також допомагає автору створити символи й образи у тексті роману та викликати ряд асоціацій у читача 3 поданим зображенням.

Оскільки іконічний складник має більший вплив на адресата ніж вербальний, можна стверджувати, що мультимодальний художній прозовий текст $є$ більш дієвим інструментом здійснення вище згаданих функцій, ніж традиційний художній прозовий текст. У подальшому дослідженні вважаємо за доцільне зосередити увагу на вивченні фрункцій параграфремних складників у мультимодальному художньому прозовому тексті. 


\section{Список літератури:}

1. Аветян Э.Г. Мера знаковости язика. Проблемы мотивированности языкового знака. Калининград : Калининград. гос. ун-т, 1976. С. 11-19.

2. Анисимова Е.Е. О целостности и связанности креолизованного текста. Коммуникативная лингвистика : сб. науч. тр. Москва : МГЛУ, 1997. С. 31-37.

3. Арнольд И.В. Значение сильной позиции для интерпретации художественного текста. Иностранные языки в школе. 1978. № 4. С. 23-31.

4. Арнольд И.В. Стилистика современного английского языка: стилистика декодирования. Москва : Просвещение, 1990. $300 \mathrm{c}$.

5. Бабенко Л.Г. Филологический анализ текста. Основы теории, принципы и аспекты анализы. Екатеринбург, 2004. 464 c.

6. Моррис Ч.У. Основания теории знаков: Семиотика / под ред. Ю.С. Степанова. Москва, 1983.260 с.

7. Сподарик О.В. Комбінаторика вживання ілюстрації як елемента полікодового художнього тексту. Лінгвістика : зб. наук. праць. Луганськ, 2012. С. 174-182.

8. Сподарик О.В. Постмодерна характеристика полікодового художнього тексту. Наукові записки. Серія «Філологічна». 2012. Вип. 27. С. 274-276.

9. Baldry A., Thibault P. Multimodal transcription and text analysis: A multimedia toolkit and coursebook / Anthony Baldry, Paul Thibault. London : Equinox, 2006. P. 270.

10. Foer J. Extremely Loud \& Incredibly Close / Jonathan Safran Foer. New York : Penguin book, 2005.341 p.

11. Kress G. Reading Images: The Grammar of Visual Design / G. Kress, T. van Leeuwen. London and New York : Routledge, 1996.

12. Lezana M. On Tangle Formationsand Fluid Narratives: Scrapbooking and Photography Inextremely Loud and Incredibly / Facultad de Letras, Pontificia Universidad Católica de Chile. 2017. URL: http://letras.uc.cl/letras/ whiterabbit/images/PDFS/ISSUES13/LEZANA.pdf

13. Nørgaard N. The Semiotics of Typography in Literary Texts: A Multimodal Approach / N. Nørgaard. 2009.

\section{References:}

1. Avetyan E.G. (1976) Mera znakovosti yazika. Problemi motivirovannosti yazyikovogo znaka [The measures of language sign. Problems of motivation of a language sign]. Kaliningrad: Kaliningrad. gos. un-t.

2. Anisimova E.E. (1997) O tselostnosti i svyazannosti kreolizovannogo tekstu [On the integrity and coherence of the creolized text]. Kommunikativnaya lingvistika [Communicative linguistics]. Moscow: MGLU, pp. 31-37.

3. Arnold I.V. (1978) Znachenie silnoy pozitsii dlya interpretatsii hudozhestvennogo teksta [The importance of strong position for the interpretation of a literary text]. Inostrannyie yazyiki $v$ shkole, no. 4, pp. $23-31$.

4. Arnold I.V. (1990) Stilistika sovremennogo angliyskogo yazyika [Modern English stylistics: decoding stylistics]. Moscow: Prosveschenie.

5. Babenko L.G. (2004) Filologicheskiy analiz teksta. Osnovyi teorii, printsipyi i aspektyi analizyi [Philological analysis of the text. Fundamentals of theory, principles and aspects of analysis]. Ekaterinburg.

6. Morris Ch.U. (1983) Osnovaniya teorii znakov [Foundations of Sign Theory: Semiotics]. Moscow, pp. 37-89.

7. Spodaryk O.V. (2012) Kombinatoryka vzhyvannia iliustratsii yak elementa polikodovoho khudozhnoho tekstu [Combinatorics implantation of illustrations as an element of polycode artistic text]. Lingvistyka [Linguistics]. Luhansk, pp. 174-182.

8. Spodaryk O.V. (2012) Postmoderna kharakterystyka polikodovoho khudozhnoho tekstu [Postmodern characteristics of polycode artistic text]. Naukovi zapysky, no. 27, pp. 274-276.

9. Baldry A., Thibault P. (2006) Multimodal transcription and text analysis: A multimedia toolkit and coursebook / Anthony Baldry, Paul Thibault. London: Equinox, p. 270.

10. Foer J. (2005) Extremely Loud \& Incredibly Close / Jonathan Safran Foer. New York: Penguin book, 341 p.

11. Kress G. (1996) Reading Images: The Grammar of Visual Design / G. Kress, T. van Leeuwen. London and New York: Routledge.

12. Lezana M. (2017) On Tangle Formationsand Fluid Narratives: Scrapbooking and Photography Inextremely Loud and Incredibly / Facultad de Letras, Pontificia Universidad Católica de Chile. URL: http://letras.uc.cl/letras/ whiterabbit/images/PDFS/ISSUES13/LEZANA.pdf

13. Nørgaard N. (2009) The Semiotics of Typography in Literary Texts: A Multimodal Approach / N. Nørgaard. 